\title{
Stop Voicing and F0 Perturbation in Pahari
}

\author{
Nazia RASHID \\ University of Azad Jammu and Kashmir (UAJ\&K), Pakistan \\ naziarasheed09@gmail.com
}

Abdul Qadir KHAN

UAJ\&K, Pakistan

aqkhan8873@yahoo.com

abdul.qadir@ajku.edu.pk
Ayesha SOHAIL

UAJ\&K, Pakistan

ayesha.sohail68@gmail.com
Bilal Ahmed ABBASI

UAJ\&K, Pakistan

itsmeabbasi@gmail.com

\begin{abstract}
The present study has been carried out to investigate the perturbation effect of the voicing of initial stops on the fundamental frequency (FO) of the following vowels in Pahari. Results show that FO values are significantly higher following voiceless unaspirated stops than voiced stops. F0 contours indicate an initially falling pattern for vowel [a:] after voiced and voiceless unaspirated stops. A rising pattern after voiced stops and a falling pattern after voiceless unaspirated stops is observed after [i:] and [u:]. These results match Umeda (1981) who found that F0 of a vowel following voiceless stops starts high and drops sharply, but when the vowel follows a voiced stop, F0 starts at a relatively low frequency followed by a gradual rise. The present data show no statistically significant difference between the F0 values of vowels with different places of articulation. Place of articulation is thus the least influencing factor.
\end{abstract}

Keywords: Pahari; perturbation; fundamental frequency; voicing; place of articulation

\section{Povzetek}

V študiji smo v paharščini raziskovali učinek zvočne premene (perturbacije) na osnovno frekvenco samoglasnika, ki se pojavi zaradi prisotnosti zvenečega zapornika pred samoglasnikom. Rezultati kažejo, da so vrednosti FO na samoglasnikih bistveno višje po nezvenečih nepridihnjenih zapornikih $v$ primerjavi $z$ njihovimi nezvenečimi zaporniškimi pari. Potek FO $\mathrm{v}$ primeru samoglasnika [a:] izkazuje prvotno padajoči vzorec po zvenečih in nezvenečih nepridihnjenih zapornikih. V primeru samoglasnikov [i:] in [u:] opažamo naraščajoči vzorec po zvenečih zapornikih ter padajoči vzorec po nezvenečih nepridihnjenih zapornikih. Rezultati se ujemajo z Umeda (1981), ki pravi, da se FO samoglasnika po nezvenečih zapornikih začne visoko in močno pade, ko pa samoglasnik sledi zvenečemu zaporniku, pa ima F0 razmeroma nizko vrednost, čemur sledi postopni dvig. Toda tokratni podatki ne kažejo statistično pomembnih razlik med vrednostmi F0 na samoglasnikih v primeru različnih zapornikov glede na mesto artikulacije. Iz teh rezultatov zaključujemo, da mesto artikulacije predhodnega zapornika najmanj vpliva na F0 samoglasnika.

Ključne besede: paharščina; zvočna premena (perturbacija); osnovna frekvenca; zvenečnost; mesto artikulacije 


\section{Introduction}

\subsection{Background of the study}

Consonantal perturbation of the fundamental frequency is an important phenomenon in the field of linguistics. It is worth investigating as it provides the basis for the theories of tonogenesis, the chronological development of tones in a language. F0 rising or falling is posited to contribute to the development of contrastive tones owing to the voicing distinction of consonants at the initial position (Chavez-Peon, 2005). In tonal languages, the same linguistic segment may convey different meanings if uttered with different tones. F0 contrast at the stop release also serves as the cue for the perception of stop laryngeal features (Whalen, Abramson, Lisker \& Mody, 1993). When other cues are ambiguous, FO serves for signaling the voicing distinction at the prevocalic position (Hanson, 2009; Kirby \& Ladd, 2015).

It is well recognized that in many languages, initial consonants characteristically perturbate the onset F0 of the vowels (Mirza, 1990). Li (1980) argues that voicing of consonants in the prevocalic position perturbates the F0 of the vowels. F0 at the onset of the vowel is associated with the phonological features of initial stops (Francis, Ciocca, Wong \& Chan, 2006).

\subsection{Historical background of the Pahari language}

Pahari is a term used for a string of various dialects spoken in different regions including the great Himalayas and Nepal (Shakil, 2004). It is the mother tongue of the millions of mountain-dwelling people. Shakil (2004) claims Pahari is one of the ancient languages of central and South Asia. The languages of the sub-continent belong to Indo European group of languages. According to Masica (1991), Indo Aryan family is the sub-branch of Indo-European languages. Nigram (1972) divides Indo-Aryan languages between the eastern group and the central northern group. Pahari belongs to the central northern group of Indo Aryan family. Pahari language is spoken almost in the entire Azad Jammu and Kashmir (AJ\&K). It is the mother tongue of most of the Kashmiri people.

\subsection{Pahari stops and vowels}

According to Khan (2011), there are twelve oral stops with four places of articulation in Pahari. These places are bilabial, dental, alveolar, and velar. Pahari stops exhibit a three-way laryngeal contrast as voicing, voiceless aspirated, and voiceless unaspirated. Voiced stops are /b, d, d g/, voiceless unaspirated stops are /p, t, t, $k$ / and voiceless aspirated stops are $/ \mathrm{p}^{\mathrm{h}}, \mathrm{t}^{\mathrm{h}}, \mathrm{t}^{\mathrm{h}}, \mathrm{k}^{\mathrm{h}} /$. There are twelve oral vowels in Pahari. Among them, six are long vowels [a:, æ:, u:, i:, o:, e:], and six are short vowels [I, e, æ, ə, o, ひ]. The present study deals with three long vowels [a:, i:, u:] taken from three dimensions; 
central, front, and back respectively. According to Khan (2014), [a:] is a central, mid, long unrounded vowel; [i:] is a high, front, long, unrounded vowel; and [u:] is a high, back, long, rounded vowel.

\section{Literature review}

\subsection{Fundamental frequency of vowels}

Fundamental frequency perceived by the human ear as the pitch is one of the certain phonetic features associated with vowels. According to $\mathrm{Xu}$ and $\mathrm{Xu}(2003 \mathrm{~b})$, it serves as a chief speech variable that provides linguistic information and performs a vital role in discourse. Pommerening and Volkner (n.d) state that by changing the fundamental frequency, speakers convey significant linguistic and paralinguistic information to the listener.

\subsection{Stops and voicing}

Stops are the most important category of consonants. Schiefer (1986) states that in the majority of languages, the stop category can easily and more accurately be analyzed in contrast with all the other consonants. It is because of some laryngeal features associated with stops i.e. voicing, breathiness, and aspiration, etc. Stops are the only category that includes all these features so it is termed as a universal category. Some languages have a three-way laryngeal contrast as aspiration, voicing, and breathiness; on the other hand, some have a four-way contrast as in most of the Indo Aryan languages (Dutta, 2007). According to Khan (2012), Pahari stops exhibit a three-way laryngeal contrast as voicing, voiceless aspirated, and voiceless unaspirated.

Voicing is an important phonological feature of stops that makes two categories of stops: voiced and voiceless. According to Chen (2011), the main consonantal distinction lies in voicing which has a close association with the F0 perturbation. Carne (2008) states that voicing distinction at initial consonants results in intrinsic perturbations in the F0 of the following vowel. There is a great influence of voicing on the acoustical characteristics including the fundamental frequency of the vowels (House \& Fairbanks, 1953).

\subsection{Stop voicing and F0 perturbation of vowels}

In most languages when vowels are preceded by consonants, the fundamental frequency of the vowels is affected by the voicing of consonants (Lofqvist, 1975). According to Hanson (2009), the initial few tens of milliseconds are considered to be influenced by the voicing properties of the preceding consonants. In some of the 
languages, the effect extends further even near to the end of the vowel length but this is less frequent. However, it is agreed that $\mathrm{FO}$ of a vowel at onset is significantly higher when it follows voiceless consonants and lower when it follows voiced ones.

As the F0 movement along the vowel contour is concerned, Wong and $\mathrm{Xu}$ (2007, p. 1293) claim that there are two opposite views. One view is 'rise-fall dichotomy' and the other is 'no-rise view'. The first view suggests that F0 is lowered after voiceless consonants and raised from a lower onset after voiced ones. According to Silverman (1986), the association of the consonant voicing and the manner of F0 movement is called 'rise-fall dichotomy'. The 'no-rise view' suggests that $\mathrm{F} 0$ is lowered after all stops.

Stop voicing and F0 perturbation has been found in the majority of the languages and has been documented widely. Major studies show that voiced stops lower whereas voiceless stops raise the $\mathrm{F} 0$ of the vowels. A general trend of the high $\mathrm{F} 0$ after voiceless stops and lower F0 after voiced stops was observed by Shimizu (1989) in five Asian languages (Japanese, Korean, Burmese, Thai, and Hindi).

F0 perturbation has been observed more at the beginning part of the vowel that lessens along the vowel length. Evidence from House and Fairbanks (1953) on the association of stops with the following vowel FO shows that average FO was lower after a voiced consonant and higher after the voiceless consonants and it was also observed that this difference in FO occurred at the onset of voicing instead of occurring throughout the vowel. The greatest effect was also observed by Carne (2008) at the onset that diminished across the duration of a vowel.

\section{Methodology}

\subsection{Research design}

The study is purely quantitative. The speakers were provided with a word list prepared by the researcher. Quantitative analysis includes the acoustic measurements of the F0 using Praat prosody pro 5.3.2. Data were spread on Microsoft excel to obtain the required values and to present the results in the form of tables and figures. Different statistical procedures and tests were applied on SPSS to check the significance of the results.

\subsection{Participants}

Six adult native speakers (three males, three females) of Pahari with ages ranging from 20-50 years were selected randomly. Their education level was between intermediate and masters. All the participants were born and in raised district Bagh and are permanent residents of this area. None of the participants reported any account of 
language impairments or any ailment that would have affected his speaking during recordings. They had normal voices and normal communicative ability.

\subsection{Stimuli}

A list of 36 monosyllabic words in the CVC context was prepared that contained Pahari stops at the initial position. Each stop was followed by vowels [a:], [i:] and [u:] leading to twelve different combinations for the single vowel. These vowels are the edge vowels that show most of the characteristics acquired by the vowel segments. They are taken from three positions; front, center, and back. Real words were chosen despite this constraint, there were five gaps in the stimuli.

\subsection{Data collection procedure}

The selected words were recorded on Praat with a frequency of $44100 \mathrm{~Hz}$. A silent room was chosen to record the language samples in a neutral pitch. A high-quality Shure SM10A-CN low impedance microphone was also employed to facilitate the recordings and to avoid background noise. The participants were asked to utter each word three times with a pause after each utterance. The repetitions of each speaker were saved as wave files on Praat.

The recorded sounds were edited on Praat prosody pro 5.3.2. The waveforms of each recorded word were segmented by marking boundaries manually across the target vowels. This procedure involved the identification of the onset of the vowel portion by the beginning of voicing after the burst of the stop. The boundaries were determined by repeatedly listening to the recordings and by the continuous inspection of the waveform. Each repetition of all the participants was labeled separately and then all were assembled. The speech analyzing software automatically located the required values of FO by identifying the mean FO and mean-norm FO. These values were taken in Hertz $(\mathrm{Hz})$ and the corresponding time locations were recorded in milliseconds (ms) when documented on Microsoft Excel.

Segmented portions were measured by employing the programmed Praat scripts. Fundamental frequency values were measured at the onset after the release of the stop and along with twelve intervals of the tonal contour via autocorrelation function of Praat. The required data were spread on Microsoft Excel to take the mean F0 and mean-norm FO values. Onset FO was taken just at the beginning of the voicing of the vowel after the burst of the stops. The data were presented in tabular form and the results were highlighted in the form of figures by employing MS Excel. 


\subsection{Data analysis procedure}

After taking the F0 values on Microsoft excel, SPSS was used for statistical analyses. Consonant was the independent variable and FO was the dependent variable. For statistical analysis, the data were gone through the independent t-test and one-way ANOVA. After obtaining all the assumed values, each research question was answered. Stop voicing effect was measured by comparing voiced stops with the voiceless counterparts. For FO contours, each vowel was analyzed separately in the context of the twelve stops. It was also checked whether the place of articulation for stops, such as bilabials, dentals, alveolars, and velars had any difference in the FO on the following vowel.

\section{Results}

Perturbation by the voicing of initial stops on the FO of the following vowels was analyzed by taking the onset F0, mean FO, and FO contours within the first $100 \mathrm{~ms}$.

\subsection{Onset FO}

Onset F0 values of [a:, i:, u:] preceded by voiced and voiceless unaspirated stops were measured to find the maximum effect of preceding stops on vowel F0. It was suggested by House and Fairbanks (1953) that the greatest effect of preceding consonant occurs at the onset of voicing that decreases along with the vowel. Following results were obtained:

Table 1: Onset F0 of [a:, i:, u:] following voiced and voiceless un-aspirated stops

\begin{tabular}{llll}
\hline Stops & Onset FO [a:] & Onset F0 [i:] & Onset F0 [u:] \\
\hline $\mathrm{p}$ & 164.09 & 173.728 & 162.812 \\
$\mathrm{~b}$ & 150.14 & 154.588 & 154.54 \\
$\mathrm{t}$ & 167.469 & 180.197 & 176.285 \\
$\mathrm{~d}$ & 156.43 & 157.503 & 156.51 \\
$\mathrm{t}$ & 169.479 & 166.923 & 171.441 \\
$\mathrm{~d}$ & 155.779 & 160.26 & 163.156 \\
$\mathrm{k}$ & 167.783 & 178.415 & 178.43 \\
$\mathrm{~g}$ & 154.137 & 154.414 & 154.893 \\
\hline
\end{tabular}




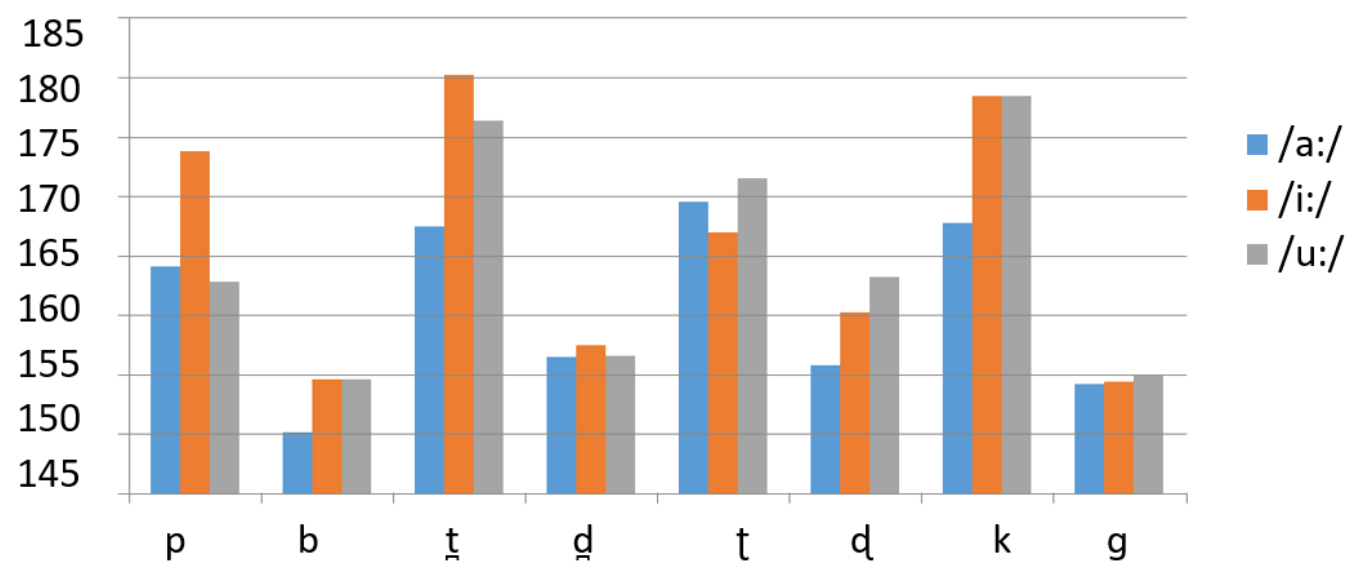

Figure 1: Onset F0 of [a:, i:, u: ] following voiced and voiceless unaspirated stops

If the onset F0 of the three vowels following voiced and voiceless unaspirated stops are compared, it is found that the F0 values of [a:] following voiceless unaspirated stops range from 160 to $170 \mathrm{~Hz}$, whereas that of [i:] range from 165 to $180 \mathrm{~Hz}$ and that of [u:] are between $162-178 \mathrm{~Hz}$. It is also found that the onset $\mathrm{F} 0$ of [a:] following voiced stops range from $150-160 \mathrm{~Hz}$, onset F0 of [i:] are in the range of $154-160 \mathrm{~Hz}$, and that of [u:] range from $155-163 \mathrm{~Hz}$. This shows that there is no big difference in the onset $\mathrm{F} 0$ of the three vowels preceded by voiced stops. On the other hand in an environment of voiceless unaspirated stops, F0 values of [i:] are the highest, and that of [a:] are the lowest. This shows that vowels' intrinsic pitch plays a role in the context of voiceless unaspirated stops. As it is not the focus of the study, further investigation is left for future studies.

\subsection{Mean F0}

Mean F0 of the vowels was analyzed to find F0 differences preceded by voiced and voiceless stops. The following results were obtained.

Table 2: Mean F0 of [a:, i:, u:] following voiced and voiceless unaspirated stops

\begin{tabular}{llll}
\hline Stops & Mean F0 [a:] & Mean F0 [i:] & Mean F0 [u:] \\
\hline P & 161.704 & 172.954 & 180.492 \\
$\mathrm{~b}$ & 156.355 & 168.183 & 174.201 \\
$\mathrm{t}$ & 164.774 & 178.527 & 181.866 \\
$\mathrm{~d}$ & 159.338 & 165.929 & 169.11 \\
$\mathrm{t}$ & 167.854 & 173.495 & 177.472 \\
$\mathrm{~d}$ & 157.635 & 168.237 & 174.702 \\
$\mathrm{k}$ & 164.781 & 179.341 & 180.513 \\
$\mathrm{~g}$ & 156.835 & 167.067 & 171.283 \\
\hline
\end{tabular}




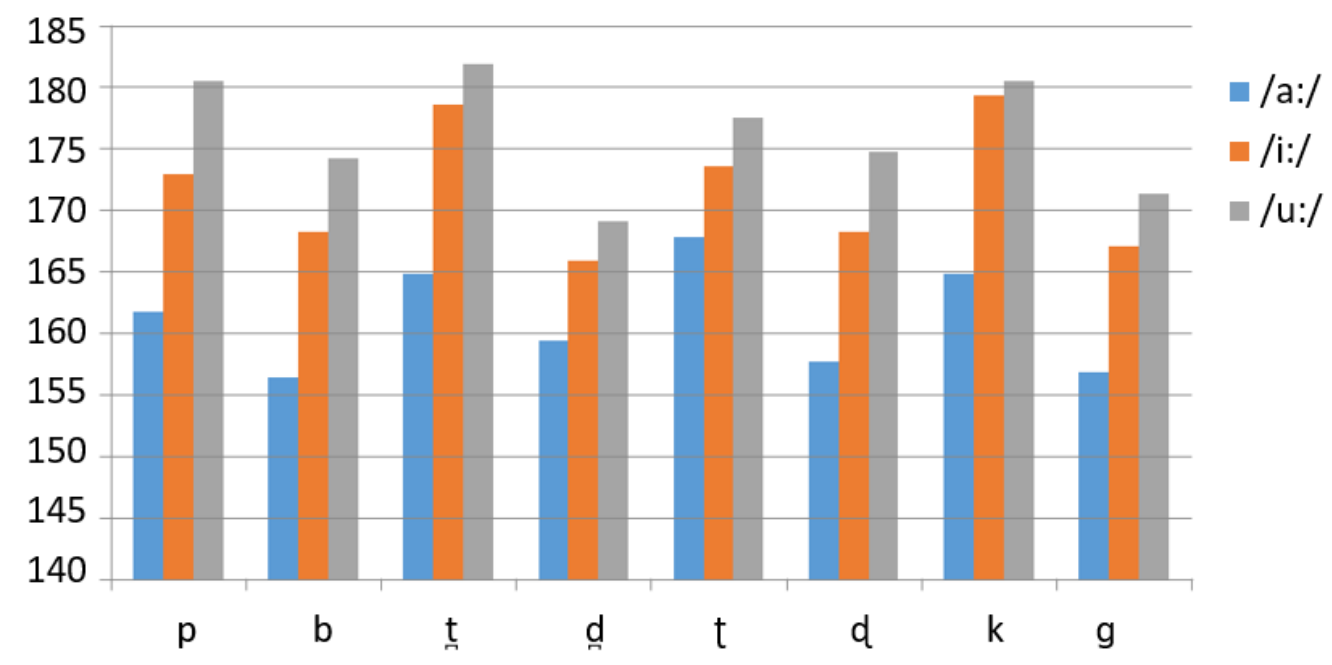

Figure 2: Mean F0 of vowels following voiced and voiceless unaspirated stops

\subsection{F0 contours of vowels following voiced and voiceless unaspirated stops}

F0 contours of vowels are also shaped by the voicing effect of the previous stops. These contours were marked by taking F0 values for each vowel over the first twelve-time intervals from the onset. According to Mirza (1990), these twelve periods constitute approximately $100 \mathrm{~ms}$ that is considered as an adequate time to exhibit any change in the F0 of vowels by preceding stops. Mohr (1971) claims that the influence of the preceding consonant on $\mathrm{F} 0$ is limited to the early portion of the vowel and does not run across the entire vowel length. It has also been found by Umeda (1981) that the effect of the preceding stop continues for $100 \mathrm{~ms}$ on the F0 of the following vowel. Moreover, in tonal languages, FO perturbation sustains for a shorter duration as compared to nontonal languages. The effect of all the stops on the F0 track of each vowel was marked and the following patterns were found: 


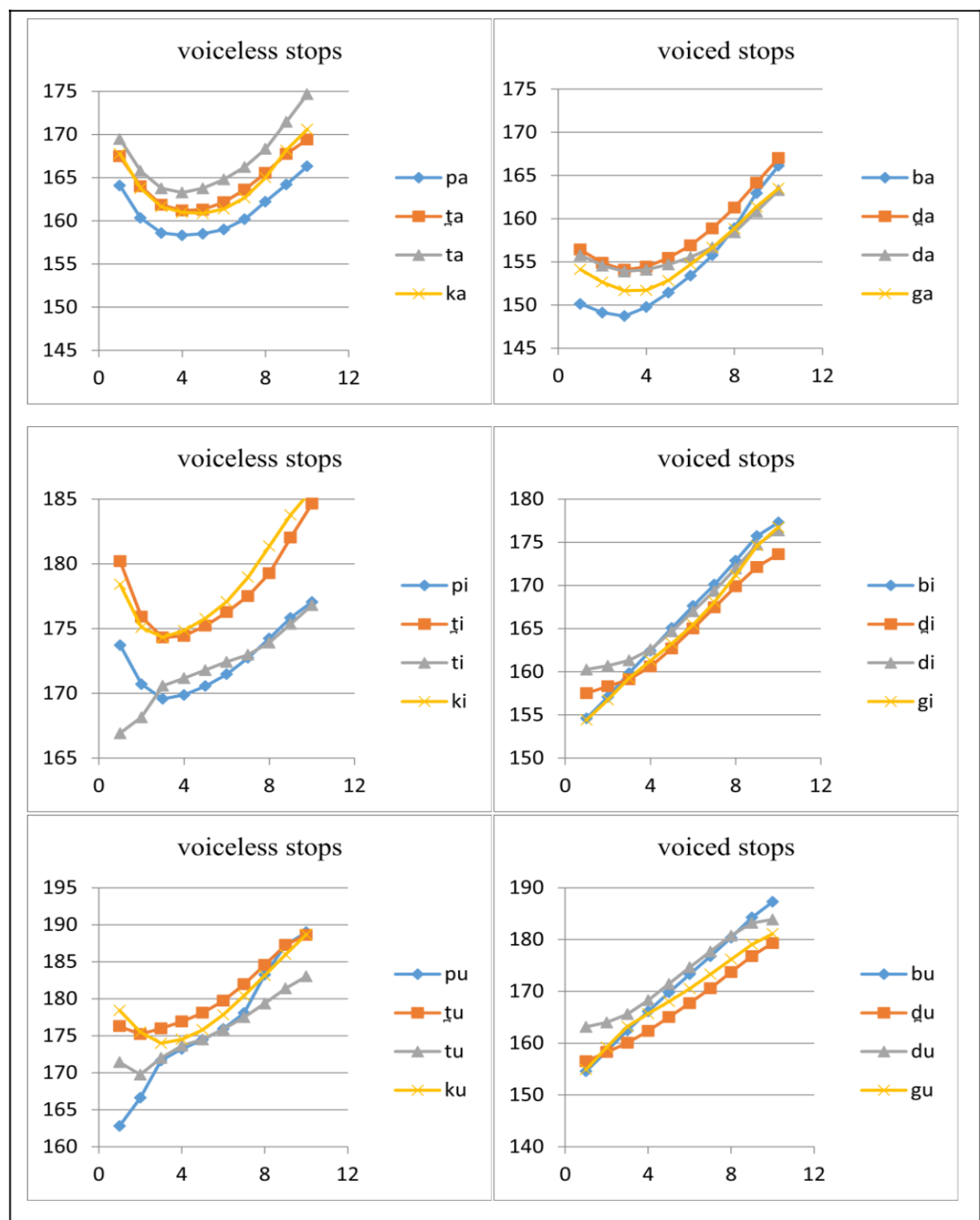

Figure 3: Average F0 contours over all speakers in $/ \mathrm{p} /$ versus $/ \mathrm{b} /, \mathrm{t} / \mathrm{versus} / \mathrm{d} / \mathrm{l} / \mathrm{t} /$ versus $/ \mathrm{d} /$, and $/ \mathrm{k} /$ versus $/ \mathrm{g} /$ at word initial position followed by vowels [a:, i:, $\mathrm{u}:]$. X-axis represents the normalized time and $y$-axis represents the fundamental frequency in $\mathrm{Hertz}(\mathrm{Hz})$

\subsubsection{F0 contours of [a:]}

F0 path of [a:] within twelve intervals of time following /p/ and /b/ depicted in Figure 3 shows that /p/ raises the fundamental frequency to $164 \mathrm{~Hz}$ that is much higher than that of $/ \mathrm{b} /(150 \mathrm{~Hz})$. When examined in the vowel duration FO of /pa:/ sharply falls to $158 \mathrm{~Hz}$ during the initial five-time intervals and rises again gradually to $166 \mathrm{~Hz}$ in the next intervals. F0 of /ba:/ slightly lowers to $148 \mathrm{~Hz}$ and then gradually rises to $166 \mathrm{~Hz}$. The figure indicates that there is a sharp fall of $6 \mathrm{~Hz}$ from a raised onset in the 
environment of voiceless unaspirated stop and a narrower fall of $2 \mathrm{~Hz}$ from a lowered onset in case of voiced stops when data from all participants are included.

Similarly, F0 contour after /t/ also shows a steep fall of $6 \mathrm{~Hz}$ from a higher onset level and rises again to $169 \mathrm{~Hz}$. Conversely the onset F0 of [a:] following /d/ slightly falls from a lower onset for about 1 hertz and then rises to $167 \mathrm{~Hz}$. Here the fall after the voiceless stop is steeper again. F0 contours of the vowel [a:] following $/ t /$ and $/ d /$ show that $\mathrm{FO}$ after /d/ falls sharply for $6 \mathrm{~Hz}$ from a raised onset before rising again. On the other hand, $\mathrm{FO}$ after /d/ is $156 \mathrm{~Hz}$ that is lower than that of /ta:/ and after a slight fall of $1 \mathrm{~Hz}$, it rises gradually to $163 \mathrm{~Hz}$. F0 trajectory of / ka:/ versus /g / shows a similar fall rise pattern. After $/ \mathrm{k} /$, there is a fall of $7 \mathrm{~Hz}$ from a raised onset and after $/ \mathrm{g} /$, there is a fall for $3 \mathrm{~Hz}$ from a lower onset.

\subsubsection{F0 contours of [i:]}

In Figure 3, F0 contours of [i:] following voiced and voiceless unaspirated stops are also represented. These contours show that F0 of /pi:/ falls for $4 \mathrm{~Hz}$ during the first fivetime intervals. $\mathrm{FO}$ of /bi:/ starts from $154 \mathrm{~Hz}$ that abruptly rises to indicate a straight contour up to $177 \mathrm{~Hz}$. Here voiced stops generate a gradual rising pattern. Likewise, the F0 path of $\mathrm{Hz}$ ) to $174 \mathrm{~Hz}$ having a fall of $6 \mathrm{~Hz}$ and rises to $184 \mathrm{~Hz}$. Conversely, instead of a fall rise pattern, /d/ continuously raises the F0 track of the following [i:] that starts from $157 \mathrm{~Hz}$ to $173 \mathrm{~Hz}$. It is demonstrated by the F0 contours of [i:] following /t/ and /d/ that F0 of the vowel following / $\mathrm{t} /$ is higher $(166 \mathrm{~Hz}$ ) that raises gradually up to 176 $\mathrm{Hz}$. Likewise, F0 after voiced /d/ is $160 \mathrm{~Hz}$ that is lower than that of /t/. It also rises gradually to $176 \mathrm{~Hz}$. F0 contours after /t, $\mathrm{d} /$ are somewhat different from the previous contours. These contours rise after both the stops although F0 is lower for voiced than after the voiceless stop. On the other hand, the F0 contour of / ki:/ shows a fall rise pattern (a fall of $4 \mathrm{~Hz}$ from 178 to $174 \mathrm{~Hz}$ ) whereas that of /gi:/ shows a continuous rise from $154 \mathrm{~Hz}$ to176 $\mathrm{Hz}$.

Data from all the participants show that there is a steep fall of F0 track from a raised onset in case of voiceless unaspirated stops (except for $/ \mathrm{t} /$ ) and a gradual rise from a lower onset in case of all voiced stops.

\subsubsection{F0 contours of [u:]}

Figure 3 also presents the $\mathrm{FO}$ contours of [u:] following voiced and voiceless unaspirated stops. It is clear that F0 of /pu:/ gradually rises from $162 \mathrm{~Hz}$ to $188 \mathrm{~Hz}$ and that of /bu:/ also rises continually from $154 \mathrm{~Hz}$ to $187 \mathrm{~Hz}$. Both the contours show a rising pattern; from a lower onset in case of voiced stop and from a higher onset in case of a voiceless stop. The perturbation of the FO by / $t /$ and /d/ indicate that the F0 path following / $\mathrm{t} /$ slightly lowers for about $1 \mathrm{~Hz}$ and then rises. Contrarily, /d/ constantly raises the F0 track of [u:] from $156 \mathrm{~Hz}$ to $179 \mathrm{~Hz}$. F0 contours of [u:], following /t/ and /d/ display 
that F0 path of /tu:/ falls initially for $2 \mathrm{~Hz}$. FO after voiced /d/ is $163 \mathrm{~Hz}$ that rises gradually. FO course of /ku:/ shows a fall rise pattern in which it shows a fall for $5 \mathrm{~Hz}$ from $178 \mathrm{~Hz}$ to $173 \mathrm{~Hz}$, whereas that of /g/ shows a continuous rise from $154 \mathrm{~Hz}$ to 181 $\mathrm{Hz}$.

\subsection{Statistical analysis and conclusions}

To check the significance of the hypothesis, the data were statistically analyzed on SPSS. For this purpose paired sample t-test was applied to examine the difference between the FO differences after voiced and voiceless unaspirated stops. Two stops in each pair were similar in all features except voicing. F0 of vowels obtained at different intervals were undergone the statistical analysis. Table 3 describes the statistical analysis based on t-values and $\mathrm{p}$-values of the obtained data.

Correlation coefficient and mean difference were also analyzed to check the resemblance between F0 values of vowels preceded by the minimal pairs of stops. In assimilating the FO where the significance between voiced and voiceless unaspirated stops is less than or equal to 0.05 , it is considered that the F0 differences are significant. In some cases where the significance is greater than 0.05 , the results show that stops have no significant effect on the Fo of the vowel. Pair sample t-test presents the following results:

Table 3: Statistical Analysis of the Voicing Effect on the FO of [a:, i:, u:]

\begin{tabular}{|c|c|c|c|c|c|c|c|}
\hline & Mean F0 & std. d & pairs & $\begin{array}{l}\text { Correlation } \\
\text { coefficient }\end{array}$ & Mean difference & t-value & $p$-value \\
\hline \multicolumn{8}{|c|}{ /a:/ } \\
\hline$p$ & 161.173 & 2.857 & & & & & \\
\hline b & 154.633 & 6.162 & pa: -ba: & 0.753 & 6.540 & 4.671 & 0.001 \\
\hline $\mathrm{t}$ & 164.423 & 2.967 & & & & & \\
\hline $\mathrm{d}$ & 158.351 & 4.439 & ta: -- da: & 0.817 & 6.072 & 7.259 & 0.000 \\
\hline t & 167.153 & 3.771 & & & & & \\
\hline d & 156.777 & 3.140 & ta:--da: & 0.931 & 10.376 & 22.976 & 0.000 \\
\hline k & 164.281 & 3.477 & & & & & \\
\hline g & 155.812 & 4.176 & ka:--ga: & 0.801 & 8.469 & 10.706 & 0.000 \\
\hline \multicolumn{8}{|c|}{ /i:/ } \\
\hline$p$ & 172.578 & 0.815 & & & & & \\
\hline b & 166.255 & 2.470 & pa: -ba: & 0.695 & 6.323 & 3.175 & 0.011 \\
\hline $\mathrm{t}$ & 164.632 & 1.867 & & & & & \\
\hline d & 164.632 & 1.867 & ța: -- da: & 0.716 & 13.347 & 10.072 & 0.000 \\
\hline
\end{tabular}




\begin{tabular}{llllllll}
\hline & & & \multicolumn{2}{l}{$\begin{array}{l}\text { Correlation } \\
\text { coefficient }\end{array}$} & Mean difference & t-value & p-value \\
\hline t & 172.015 & 0.957 & & & & & \\
d & 156.777 & 3.140 & ta:--da: & 0.944 & 5.117 & 4.960 & 0.001 \\
k & 166.898 & 1.887 & & & & & \\
g & 165.096 & 2.373 & ka:--ga: & 0.844 & 13.440 & 9.079 & 0.000 \\
\hline lu:/ & & & & & & \\
\hline p & 176.219 & 2.671 & & & & & \\
b & 171.324 & 3.482 & pa: --ba: & 0.987 & 4.895 & 5.151 & 0.001 \\
t & 180.462 & 1.547 & & & & & \\
d & 167.021 & 2.506 & ta: -- da: 0.977 & 13.441 & 12.833 & 0.000 \\
t & 175.852 & 1.396 & & & & & \\
d & 173.258 & 2.503 & ta:--da: & 0.982 & 4.595 & 3.016 & 0.005 \\
k & 179.430 & 1.595 & & & & & \\
g & 169.112 & 2.708 & ka:--ga: & 0.798 & 10.318 & 5.969 & 0.000 \\
\hline
\end{tabular}

The rows in front of [a:] show the significance of the obtained results in a voiced voiceless context. The first row of Table 3 reveals that /pa:/ and /ba:/ are less correlated as evident from their correlation coefficient of 0.753 . It means that vowel [a:] following this pair of stops differs in $\mathrm{FO}$ frequencies. There is a maximum difference (6.540) in the mean of the pair. The significant difference is depicted by $(t=4.671)$ and $(\mathrm{p}<0.05)$. Similarly, $/ \mathrm{t} / \mathrm{and} / \mathrm{d} / \mathrm{have}$ greater mean difference (6.072) and significant $(\mathrm{t}=7.25$ and $\mathrm{p}<0.05)$. Comparing / $\mathrm{ta}$ // and / $\mathrm{da}$ // on similar lines depicts that this pair of consonants has less correlation and less mean difference but there is a significant difference between their $\mathrm{F} 0$ as shown by $(t=22.976)$ and $(p<0.05)$. The case with /ka:/ and /ga:/ is pretty similar as evident from $(t=10.706)$ and $(p<0.05)$. This pair has a highly significant difference in the FO values.

The second group of rows depicts the statistical analysis F0 of [i:] on similar grounds. /pi:/ and /bi:/ are less correlated as their correlation coefficient (0.659) shows. There is a difference in their mean (6.323) as well. The significant difference is represented by $(t=3.175)$ and $(p<0.05)$. A similar comparison of /tii:/ and /di:/ depicts that this minimal pair has a significant difference between the F0 as shown by its $(\mathrm{t}=10.072)$ and $(\mathrm{p}<0.05)$. Pair / $\mathrm{ti}$ // and / di:/ also have a greater mean difference (5.117). Its t-value (4.960) and $(p<0.05)$ also illustrate the significant difference. Corresponding is the case of / $\mathrm{ki}: /$ and /gi:/ as apparent from $(\mathrm{t}=9.079)$ and $(\mathrm{p}<0.05)$. This pair is less correlated as its correlation coefficient (0.844) shows. The mean difference (13.440) is also great.

The third group of rows reveals that minimal pair /pu:/ and /bu:/ also has less correlation (0.987). There is a maximum difference of 4.895 in their mean. This pair has 
$(\mathrm{t}=5.151)$ and $(\mathrm{p}<0.05)$. Likewise /tu:/ and /du:/ have large mean difference 13.441, less correlation coefficient 0.977 , and significant $(t=12.833)$ and $(p<0.05)$. There is also a significant difference between the F0 of /tu:/ and /du:/ as shown by its ( $\mathrm{t}=3.016)$ and $(\mathrm{p}<0.05)$. $/ \mathrm{ku} /$ versus /gu:/ difference is also significant as depicted by $\mathrm{t}=5.969$ and $p<0.05$. The statistical analysis confirms that there is a significant difference between the F0 of vowels preceded by voiced and voiceless unaspirated stops.

Besides influencing the onset F0, preceding stops influence shaping the entire F0 contours of the vowels. The close examination of the F0 track of vowel [a:] shows that the FO falls during the first five intervals and rises again during the next intervals after all stops. It is also observed that there is a steep from raised onset level after voiceless unaspirated stops $/ \mathrm{p}, \mathrm{t}, \mathrm{t}, \mathrm{k} /$ and a shallower fall from the lowered onset after voiced stops $/ b, d, d g /$. A very similar F0 pattern of vowels having an initially falling and then rising pattern after voiceless consonants were observed by Lea (1973).

Literature reveals two views about stop voicing and F0 perturbation; 'rise-fall dichotomy' and 'no-rise view' (Wong \& Xu, 2007, p. 1293). F0 contours of [a:] align with 'no-rise view'. This view states that F0 declines, after all, stops including voiced and voiceless stops. F0 contours of [a:] show the same pattern of F0 falling after both types of stops. Ohde (1984) also found 'no-rise view' as the F0 was falling in almost all the contexts. After voicing onset a considerable fall was observed for both voiced and voiceless stops and he also added that F0 after voiced stops was slightly falling which is exactly explicated by the F0 paths of [a:] after voiced stops.

For paths of vowel /i:/ after voiceless unaspirated stops / $\mathrm{p}, \mathrm{t}, \mathrm{k} /$ show a similar pattern as that of [a:]. These stops raise the onset fundamental frequency of [i:] to a higher level which abruptly shows a steep fall and rises again after the first five intervals. Korean too shows an abrupt fall after voiceless tense stops (Shimizu, 1989). However, the F0 path after/t/ shows dissimilarity in the current study as it shows a continuous rising pattern. It also falsifies the 'no-rise view' that F0 falls after both types of stops. On the other hand, F0 after voiced stops / $b, d, d g /$ shows a continuous rising pattern from a lower onset. F0 contours of [i:] after voiced stops are in great alignment with the general rising trend found by other studies. Except for / $t$ / all stops confirm the 'risefall dichotomy'. Quite similar results were found by Umeda (1981, p. 350) who found that FO of a vowel following voiceless stops starts high and drops sharply, but when the vowel follows a voiced stop, F0 starts at a relatively low frequency followed by a gradual rise.

F0 contours of [u:] following voiced and voiceless unaspirated stops are also comparable with that of the vowel [i:] having an exception of $/ p /$ that gradually raises the F0 instead of lowering. It shows a negation of 'rise-fall dichotomy'. All the other voiceless unaspirated stops show the falling pattern from the raised onset. It is seen that except for $/ \mathrm{k} /$, the fall is not much steeper. There is a slight lowering of the $\mathrm{F} 0$ and then a rising pattern is observed. $/ \mathrm{k} /$ causes a bit steep fall. On the other hand, all the 
voiced stops generate a continuous rising pattern of F0 from a lowered onset. According to Shimizu (1989) in Japanese and Hindi, FO curves after voiced stops also show a continuous rising pattern.

F0 contours of [u:] following voiced and voiceless unaspirated stops are also comparable with that of the vowel [i:] having an exception of /p/ that gradually raises the F0 instead of lowering. It shows a negation of 'rise-fall dichotomy'. All the other voiceless unaspirated stops show the falling pattern from the raised onset. It is seen that except for $/ \mathrm{k} /$, the fall is not much steeper. There is a slight lowering of the F0 and then a rising pattern is observed. $/ \mathrm{k} /$ causes a bit steep fall. On the other hand, all the voiced stops generate a continuous rising pattern of F0 from a lowered onset. According to Shimizu (1989) in Japanese and Hindi, FO curves after voiced stops also show a continuous rising pattern.

To conclude, it may be said that voicing is a distinctive feature in Pahari and the results show that voicing of initial stops has a strong influence on the following vowel F0. There is a significant difference between the FO values of three vowels following voiced and voiceless stops. F0 is raised by voiceless unaspirated stops and lowered by voiced stops at the onset. Moreover, the FO contours of the vowels are also shaped by the influence of the preceding stop. F0 track of the vowel [a:] is lowered after both types of stops that align with 'no-rise view'. On the other hand, FO paths of [i:] and [u:] show a continuous rising after voiced stops and lowering after voiceless stops confirming the 'rise-fall dichotomy' with two surprising and even unpredicted results of /ti:/ and /pu:/. These two F0 paths constantly rise instead of falling.

So, Pahari voiceless and voiced stops induce a high and low pitch on the following vowel respectively. This pitch distinction at the prevocalic position is attributed to change the tone of the vowel, hence the tone of the entire utterance. Tonal variation is considered to be one of the factors responsible for tonogenesis in a language. Pahari stops with voicing distinction have a strong tone inducing effect.

\section{References}

Ahmed, S. (2002). A Comparative study of English and Pahari (Unpublished M.A. Thesis). National University of Modern Languages, Islamabad.

Bradshaw, M. M. (1999). A crosslinguistic study of consonant-tone interaction. Doctoral dissertation, The Ohio State University.

Carne, M. J. (2008). Intrinsic consonantal FO perturbation in 3-way VOT contrast and its implications for aspiration-conditioned tonal split: Evidence from Vietnamese. In INTERSPEECH, 2294-2297.

Chavez-Peon, M. E. (2005). The effects of implosives and prenasalized stops on pitch in Shona. The Journal of the Acoustical Society of America, 117(4), 2461-2461. 
Chen, Y. (2011). How does phonology guide phonetics in segment-F0 interaction?. Journal of Phonetics, 39(4), 612-625.

Dutta, I. (2007). Four-way stop contrasts in Hindi: An acoustic study of voicing, fundamental frequency and spectral tilt. Ph.D. dissertation, University of Illinois at Urbana Champaign.

Francis, A., Ciocca, V., Wong, V., \& Chan, J. (2006). Is fundamental frequency a cue to aspiration in initial stops?. The Journal of the Acoustical Society of America, 120(5), 2884.

Hanson, H. M. (2009). Effects of obstruent consonants on fundamental frequency at vowel onset in English. The Journal of the Acoustical Society of America, 125(1), 425-441.

House, A. S., \& Fairbanks, G. (1953). The influence of consonant environment upon the secondary acoustical characteristics of vowels. The Journal of the Acoustical Society of America, 25(1), 105-113.

Karnai, M. K. (2007). Parahri aur Urdu: Ik Taqabali Jaiza. Islamabad: National Language Authority.

Khan, A. Q. (2014). An Acoustic Study of Pahari Oral Vowels. Lingua Posnaniensis, 56(2), 29-40.

Khan, A. Q. (2012). Phonology of Pahari: A study of segmental and suprasegmental features of Poonch Dialect (Unpublished Doctoral Dissertation). University of AJ\&K, Muzaffarabad.

Khan, A. Q. (2011). An Acoustic Study of VOT in Pahari Stops. Kashmir Journal of Language Research, 14(1), 111-128.

Kirby, J., \& Ladd, D. R. (2015). Stop voicing and F0 perturbations; evidence from French and Italian. $18^{\text {th }}$ International Congress of Phonetic Sciences, Glasgow, UK.

Lea, W. A. (1973). Influences of phonetic sequences and stress on fundamental frequency contours of isolated words. The Journal of the Acoustical Society of America, 53(1), 346.

Lehiste, I., \& Peterson, G. E. (1961). Some basic considerations in the analysis of intonation. The Journal of the Acoustical Society of America, 33(4), 419-425. K“ D"B Institute of History and Philology Academia Sinica 51, 1-13.

Lofqvist, A. (1975). Intrinsic and extrinsic F0 variations in Swedish tonal accents. Phonetica, 31(3-4), 228-247.

Masica, C. P. (1991). The indo-aryan languages. Cambridge University Press.

Mirza, J.S. (1990). F0 perturbation effects of prevocalic stops on Punjabi tones. Proceedings of the Australasian Speech Science and Technology Association, 90, 400-405.

Mohr, B. (1971). Intrinsic variations in the speech signal. Phonetica, 23(2), 65-93.

Nigram, R. C. (1972). Language handbook on mother tongue in census (Census of India, 1971). New Delhi: Government of India (Census Centenary Monograph No.10).

Ohde, R. N. (1984). Fundamental frequency as an acoustic correlate of stop consonant voicing. The Journal of the Acoustical Society of America, 75(1), 224-230.

Pommerening, K., \& Volkner, M. Consonant-dependent F0 variation. Retrieved from http://www.ipds.uni-kiel.de/pub_exx/aipuk/aipuk_37/37_4_PommereningVoelkner.pdf

Sapir, S. (1989). The intrinsic pitch of vowels: theoretical, physiological, and clinical considerations. Journal of Voice, 3(1), 44-51.

Schiefer, L. (1986). FO in the production and perception of breathy stops: Evidence from Hindi. Phonetica, 43(1-3), 43-69.

Shakil, M. (Ed.).(2004). Chitka. International Pahari Literary Society. 
Shimizu, K. (1989). A cross-language study of voicing contrasts of stops. America, 66(4), 10011017.

Silverman, K. (1986). F0 segmental cues depend on intonation: The case of the rise after voiced stops. Phonetica, 43(1-3), 76-91.

Umeda, N. (1981). Influence of segmental factors on fundamental frequency in fluent speech. The Journal of the Acoustical Society of America, 70(2), 350-355.

Whalen, D., Abramson, A., Lisker, L., \& Mody, M. (1993). F0 gives voicing information even with unambiguous voice onset times. The Journal of the Acoustical Society of America, 93(4), 2152.

Wong, Y. W., \& Xu, Y. (2007). Consonantal perturbation of FO contours of Cantonese tones. In Proceedings of the $16^{\text {th }}$ International Congress of Phonetic Sciences, 1293- 1296.

$\mathrm{Xu}, \mathrm{C} . \mathrm{X} ., \mathrm{Xu}, \mathrm{Y}$. (2003b, April). FO perturbations by consonants and their implications on tone recognition. Acoustics, Speech, and Signal Processing, Proceedings. (ICASSP'03). IEEE, 1, 1456.

Xu, Y. (2006). Principles of tone research. Proceedings of International Symposium on tonal aspects of languages, 3-13. 